\title{
Immunohistochemical expression of p53, p16 and hTERT in oral squamous cell carcinoma and potentially malignant disorders
}

\begin{abstract}
Aline Correa Abrahao(a)
Beatriz Venturi Bonelli(b)

Fábio Daumas Nunes(c)

Eliane Pedra Dias ${ }^{(d)}$

Márcia Grillo Cabral(a)
\end{abstract}

(a) Department of Oral Pathology and Oral Diagnosis, Dental School, Federal University of Rio de Janeiro, Rio de Janeiro, RJ, Brazil.

(b) Oral Pathologist of the Air Force Central Hospital, Rio de Janeiro, RJ, Brazil.

(c) Department of Oral Pathology, Dental School, University of São Paulo, São Paulo, SP, Brazil.

(d) Department of Pathology, Medical School, Fluminense Federal University, Niterói, RJ, Brazil.

\section{Corresponding author:}

Márcia Grillo Cabral

Federal University of Rio de Janeiro, School of Dentistry, Department of oral Pathology and Oral Diagnosis

Av. Professor Rodolpho Paulo Rocco, 325 -

$1^{\circ}$ andar - Cidade Universitária

Rio de Janeiro - RJ - Brazil

CEP: 21941-913

E-mail:marcia.grillo@gmail.com

Received for publication on Aug 24, 2010 Accepted for publication on Nov 16, 2010

\begin{abstract}
Oral carcinogenesis is a multi-step process. One possible step is the development of potentially malignant disorders known as leukoplakia and erytroplakia. The objective of this study was to use immunohistochemistry to analyze the patterns of expression of the cell-cycle regulatory proteins $\mathrm{p} 53$ and $\mathrm{p} 16^{\mathrm{INK} 4 \mathrm{a}}$ in potentially malignant disorders (PMD) of the oral mucosa (with varying degrees of dysplasia) and in oral squamous cell carcinomas (OSCC) to correlate them with the expression of telomerase (hTERT). Fifteen PMD and 30 OSCC tissue samples were analyzed. Additionally, 5 cases of oral epithelial hyperplasia $(\mathrm{OEH})$ were added to analyze clinically altered mucosa presenting as histological hyperplasia without dysplasia. p53 positivity was observed in $93.3 \%$ of PMD, in $63.3 \%$ of OSCC and in $80 \%$ of OEH. Although there was no correlation between p53 expression and the grade of dysplasia, all cases with severe dysplasia presented p53 suprabasal immunoexpression. p16 ${ }^{\mathrm{INK} 4 \mathrm{a}}$ expression was observed in $26.7 \%$ of PMD, in $43.3 \%$ of OSCC and in 2 cases of OEH. The $16^{\text {INK4a }}$ expression in OEH, PMD and OSCC was unable to differentiate non-dysplastic from dysplastic oral epithelium. hTERT positivity was observed in all samples of $\mathrm{OEH}$ and PMD and in $90 \%$ of OSCC. The high hTERT immunoexpression in all three lesions indicates that telomerase is present in clinically altered oral mucosa but does not differentiate hyperplastic from dysplastic oral epithelium. In PMD of the oral mucosa, the $\mathrm{p} 53$ immunoexpression changes according to the degree of dysplasia by mechanisms independent of $\mathrm{p} 16^{\mathrm{INK4a}}$ and hTERT.
\end{abstract}

Descriptors: Mouth Neoplasms; Tumor Suppressor Protein p53; CyclinDependent Kinase Inhibitor p16; Telomerase.

\section{Introduction}

Oral carcinogenesis is a multi-step process involving gene mutations and chromosomal abnormalities. ${ }^{1}$ The transition from normal oral epithelium to oral dysplasia and cancer results from accumulated genetic and epigenetic alterations. ${ }^{2}$ Common early events associated with potentially malignant disorders (PMD) of the oral mucosa include inactivation of the tumor suppressor genes TP53 and CDKN2A.,2 Point mutations in TP53 occur in $10-17 \%$ of PMD and in $35-67 \%$ of oral squamous cell carcinoma (OSCC). ${ }^{3}$ In PMD, a suprabasal p53 immunohistochemi- 
cal staining has been considered to be predictive for malignant transformation and progression to OSCC. ${ }^{3}$ p53 expression in OSCC apparently does not correlate with differentiation grade but has been associated with patient outcome. ${ }^{4,5}$

The CDKN2A gene is inactivated in approximately $70 \%$ of human cancers. ${ }^{6}$ Its codified protein p16 ${ }^{\text {INK4a }}$ is a cell-cycle inhibitor that acts in the pRbp16 ${ }^{\text {INK4a }}$ tumor suppressive pathway. ${ }^{6}$ Both PMD and OSCC have been linked to inactivation of the CDKN2A gene by homozygous deletion. ${ }^{7}$

Other mechanisms may also contribute to dysplastic cell clonal expansion and tumor progression, such as the ability of cells to regain the capacity to overcome growth arrest by rebuilding telomeric DNA. ${ }^{7,8}$ Telomeres are chromatin structures that cap the ends of eukaryotic chromosomes and ensure chromosome stability. ${ }^{8}$ At each DNA replication cycle, 30-150 base pairs of telomeric DNA are lost, driving cells into a metabolic state of irreversible growth arrest and replicative senescence. ${ }^{8}$ Telomerase is the enzyme in charge of rebuilding telomeres and is not expressed in normal somatic cells. ${ }^{7,8}$ The expression of telomerase in transformed oral epithelial cells could contribute to clonal expansion and to overcoming irreversible growth. ${ }^{8}$

Approximately $90 \%$ of primary human cancers show telomerase activity, evidenced by expression of the enzyme's catalytic subunit, hTERT (human telomerase reverse transcriptase), which is encoded by the TERT gene. ${ }^{9}$ However, the role of telomerase in oral carcinogenesis is unknown. ${ }^{10}$

The purpose of this study was to investigate $\mathrm{p} 53$, p16 ${ }^{\text {INK4a }}$ and hTERT immunohistochemical expression in PMD of the oral mucosa and OSCC and to evaluate correlations between their expression levels in these lesions.

\section{Material and Methods Tissue Samples}

Fifty formalin-fixed, paraffin-embedded biopsy specimens were retrieved from the Oral Pathology and Diagnosis Department of Federal University of Rio de Janeiro and from the Pathology Department of Fluminense Federal University archives. The samples used were 15 potentially malignant disorders (PMD) and 30 oral squamous cell carcinomas (OSCC). The lesions were classified according to World Health Organization criteria., ${ }^{111}$ Five oral epithelial hyperplasia $(\mathrm{OEH})$ samples were also added to the study to analyze hyperplastic oral mucosa without dysplasia. The PMD were clinically identified as leukoplakia or erytroplakia and were graded according to the presence of epithelial dysplasia as mild, moderate or severe. ${ }^{1,11}$ The OSCC were classified as well-differentiated (WD) or poorly differentiated (PD). ${ }^{1}$ Patients' clinical data are summarized in Table 1.

Table 1 - Patients' clinical data.

\begin{tabular}{|c|c|c|c|c|c|c|c|}
\hline & \multirow{3}{*}{ Clinical data } & \multicolumn{6}{|c|}{ Lesion } \\
\hline & & \multirow{2}{*}{$\begin{array}{c}\text { OEH } \\
(n=5)\end{array}$} & \multicolumn{3}{|c|}{$\operatorname{PMD}(n=15)$} & \multicolumn{2}{|c|}{$\operatorname{Oscc}(n=30)$} \\
\hline & & & $\begin{array}{l}\text { Mild } \\
(n=5)\end{array}$ & $\begin{array}{c}\text { Moderate } \\
(\mathrm{n}=8)\end{array}$ & $\begin{array}{l}\text { Severe } \\
(n=5)\end{array}$ & $\begin{array}{c}\text { WD } \\
(\mathrm{n}=17)\end{array}$ & $\begin{array}{c}\text { PD } \\
(n=13)\end{array}$ \\
\hline & Mean age & 60 & 63.4 & 68.2 & 62.5 & 59.1 & 65.25 \\
\hline \multirow{2}{*}{ Gender } & Female & $3(60 \%)$ & $4(80 \%)$ & $2(40 \%)$ & $3(60 \%)$ & $6(35.3 \%)$ & $4(30.77 \%)$ \\
\hline & Male & 2 (40\%) & $1(20 \%)$ & $3(60 \%)$ & $2(40 \%)$ & $11(64.7 \%)$ & 9 (69.23\%) \\
\hline \multirow{5}{*}{ Site } & Tongue & 0 & $2(40 \%)$ & 1 (20\%) & $2(40 \%)$ & $8(47.06 \%)$ & $3(23.08 \%)$ \\
\hline & Buccal mucosa & 0 & $1(20 \%)$ & $3(60 \%)$ & 0 & $3(17.65 \%)$ & $1 \quad(7.69 \%)$ \\
\hline & Floor of the mouth & 0 & 0 & 0 & 1 (20\%) & 2 (11.76\%) & $3(23.08 \%)$ \\
\hline & Gingiva/alveolar ridge & $5(100 \%)$ & $2(40 \%)$ & $1(20 \%)$ & $2(40 \%)$ & $3(17.65 \%)$ & $6(46.15 \%)$ \\
\hline & Palate & 0 & 0 & 0 & 0 & $1 \quad(5.88 \%)$ & 0 \\
\hline
\end{tabular}

$\mathrm{OEH}=$ oral epithelial hyperplasia; $\mathrm{PMD}=$ potentially malignant disorders; $\mathrm{OSCC}=$ oral squamous cell carcinoma; $W D=$ well-differentiated; $P D=$ poorly differentiated. 


\section{Immunohistochemistry}

The streptavidin-biotin standard protocol was performed. Paraffin-embedded tissues were cut into $3 \mu \mathrm{m}$ thick sections, placed over slides, deparaffinized in xylene and rehydrated in graded alcohol. Antigen retrieval was performed with Target antigen retrieval solution $\mathrm{pH} 9$ (Dako A/S, CA, USA) in a water bath, followed by incubation with $6 \%$ hydrogen peroxide to quench endogenous peroxidase. The sections were then incubated in blocking solution (3\% bovine serum albumin) for 1 hour at room temperature, followed by primary antibody incubation, previously diluted in blocking solution. Anti-p53 (clone DO-7, 1:200 dilution - DAKO A/S, CA, USA) and anti-hTERT (Novocastra ${ }^{\circledR}$, clone 44F12, 1:75 dilution - Leica Microsystems, Berlin, Germany) antibodies were incubated for 30 minutes at room temperature, and the $\mathrm{p} 16^{\mathrm{INK} 4 \mathrm{a}}$ antibody $\left(\mathrm{CINtec}^{\mathrm{TM}}\right.$ Histology kit, clone E6H4, 1:250 dilution - DAKO A/S, CA, USA) was incubated overnight at $4^{\circ} \mathrm{C}$. Sections were exposed to the $\mathrm{LSAB}^{\mathrm{TM}}$ system (DAKO A/S, CA, USA), developed in diaminobenzidine (Dako A/S, CA, USA) and counterstained in Mayer's hematoxylin.

Positive immunohistochemistry expression of $\mathrm{p} 53, \mathrm{p} 16^{\mathrm{INK} 4 \mathrm{a}}$ and hTERT was defined by a nuclear, nuclear and cytoplasmic, and nuclear (evidenced by nucleolar positivity) staining pattern of epithelial cells, respectively. The results are expressed in both the number of positive cases and the percentage of immunostained cells after counting 100 cells in 10 consecutive high-power fields. p53 labeling in $\mathrm{OEH}$ and PMD was also evaluated as described previous- ly by Cruz et al:: ${ }^{3}$ basal when confined to the basal layer; and suprabasal when both basal and suprabasal layers were positive.

Pearson correlation, Fisher's exact test, KruskallWallis and Mann Whitney tests were used for statistical analysis, and were performed with GraphPad Prism 5.00 (GraphPad Software, CA, USA). A p value less than $0.05(\mathrm{p}<0.05)$ was considered statistically significant.

\section{Results}

The immunohistochemical results of $\mathrm{p} 53$, hTERT and $16^{\mathrm{INK} 4 \mathrm{a}}$ in OEH, PMD and OSCC are summarized in Table 2. Positive p53 cases were a common event in all study groups. In 7 PMD and in the entire OEH group, a basal p53 staining pattern was found (Figure 1). An additional 7 cases of PMD showed a suprabasal p53 staining pattern (Figure 1). There was no statistical difference between dysplasia degree and staining pattern in PMD samples. p53 positivity was also frequent in OSCC (Figure 2). No statistical difference was found between welldifferentiated and poorly differentiated OSCC cases $(\mathrm{p}>0.05)$.

Positive hTERT immunostained nuclei were observed through all epithelial cell layers in OEH and PMD (Figure 1). In the latter, no distinction was found between dysplasia grades and hTERT positivity $(p>0.05)$. The majority of the OSCC cases were positive for hTERT staining (Figure 2), and no differences were found between WD and PD OSCC samples $(p>0.05)$.

Positive $\mathrm{p} 16^{\mathrm{INK} 4 \mathrm{a}}$ immunostaining in $\mathrm{OEH}$ and

Table 2 - Distribution of positive cases in oral epithelial hyperplasia (OEH), potentially malignant disorders (PMD) and oral squamous cell carcinoma (OSCC), in accordance to p53, p16 ${ }^{\text {INK4a }}$ and hTERT.

\begin{tabular}{|c|c|c|c|c|c|c|c|c|c|}
\hline \multirow{2}{*}{\multicolumn{2}{|c|}{$\begin{array}{l}\text { Lesion } \\
\text { antibody }\end{array}$}} & \multirow{2}{*}{$\begin{array}{c}\text { OEH } \\
(n=5)\end{array}$} & \multicolumn{4}{|c|}{ PMD } & \multicolumn{3}{|c|}{ Oscc } \\
\hline & & & $\begin{array}{c}\text { Mild } \\
(n=5)\end{array}$ & $\begin{array}{l}\text { Moderate } \\
(\mathrm{n}=5)\end{array}$ & $\begin{array}{l}\text { Severe } \\
(\mathrm{n}=5)\end{array}$ & $\begin{array}{c}\text { Total } \\
(n=15)\end{array}$ & $\begin{array}{c}\text { WD } \\
(n=17)\end{array}$ & $\begin{array}{c}P D \\
(n=13)\end{array}$ & $\begin{array}{c}\text { Total } \\
(n=30)\end{array}$ \\
\hline \multirow{2}{*}{ p53 } & $B^{a}$ & $4 \quad(80 \%)$ & 2 (13.3\%) & 5 (33.3\%) & 0 & $7 \quad(46.6 \%)$ & \multirow{2}{*}{12 (40\%) } & \multirow{2}{*}{7 (23.3\%) } & \multirow{2}{*}{19 (63.3\%) } \\
\hline & $\mathrm{SB}^{\mathrm{b}}$ & 0 & 2 (3.3\%) & 0 & $5(33.3 \%)$ & $7 \quad(46.6 \%)$ & & & \\
\hline \multicolumn{2}{|c|}{ hTERT } & 5 (100\%) & 5 (33.3\%) & 5 (33.3\%) & 5 (33.3\%) & 15 (100\%) & 15 (50\%) & 12 (40\%) & 27 (90\%) \\
\hline \multicolumn{2}{|c|}{$\mathrm{p} 16^{\mathrm{INK} 4 \mathrm{a}}$} & 2 (40\%) & 2 (13.3\%) & 2 (13.3\%) & 0 & $4 \quad(26.6 \%)$ & 7 (23.3\%) & $6(20 \%)$ & $13(43.3 \%)$ \\
\hline
\end{tabular}

'Basal cell layer; 'bSuprabasal cell layer 

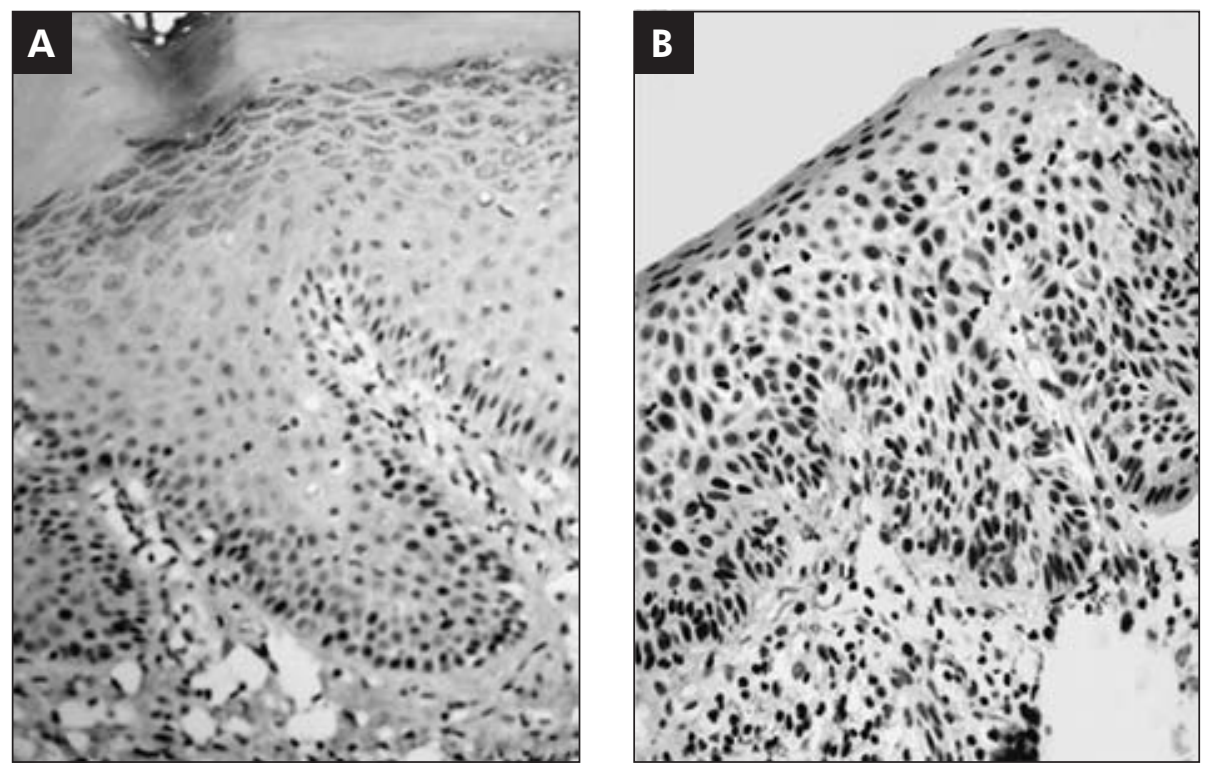

Figure 1 - Protein $\mathrm{IHC}$ expression in PMD. A: p53 expression in basal epithelial cell layer; $\mathbf{B}:$ p53 expression in suprabasal epithelial cell layers; C: p $16^{\text {INK4a }}$ expression in small cell groups; D: hTERT expression throughout epithelial cell layers. (SAB - original magnification 200x).
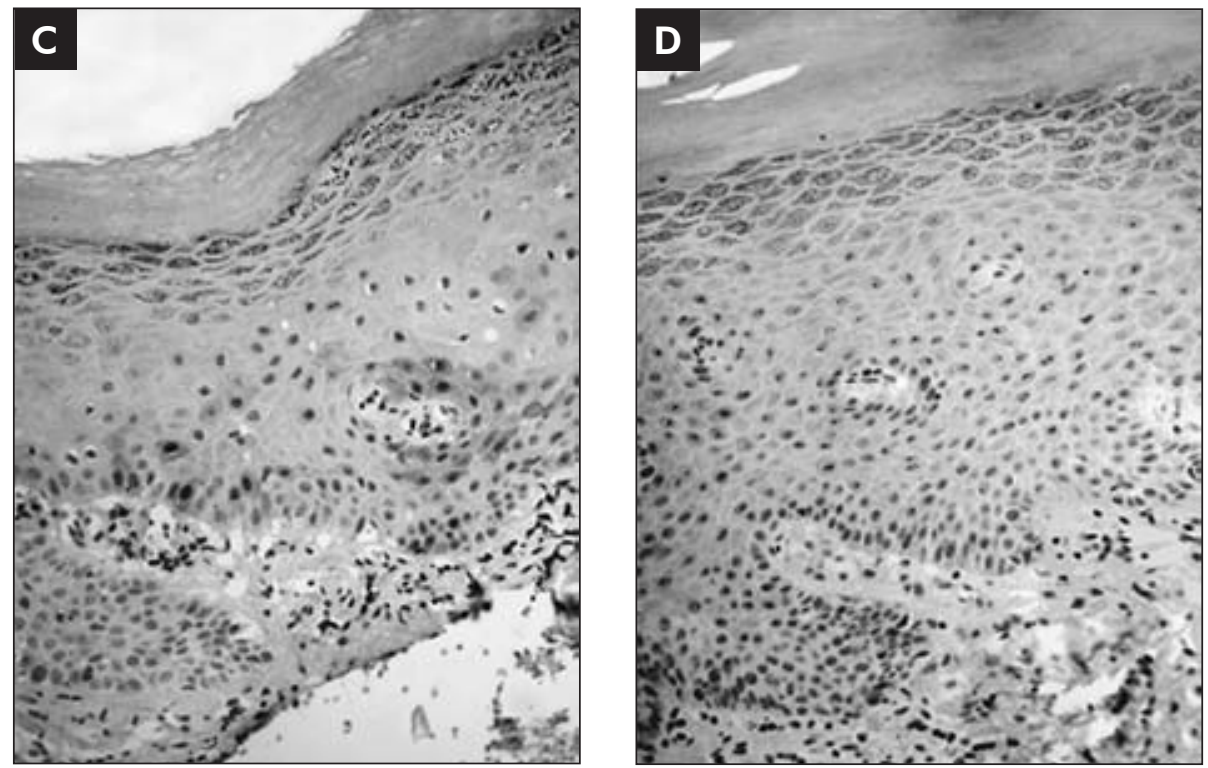

PMD showed stained cells arranged in clusters with skip areas in basal and suprabasal epithelial cell layers (Figure 1). No correlation between dysplasia grade and $\mathrm{p} 16^{\mathrm{INK} 4 a}$ was observed $(\mathrm{p}>0.05)$. In the OSCC group, positive $\mathrm{p} 16^{\mathrm{INK} 4 \mathrm{a}}$ cases were uncommon and two staining patterns were identified. Ten cases presented positive cells organized in small isolated clusters, and the remaining three presented extensive sheets of immunostained cells (Figure 2). There was no correlation between $\mathrm{p} 16^{\mathrm{INK} 4 \mathrm{a}} \mathrm{immu}-$ noexpression with WD or PD OSCC histological grades $(\mathrm{p}>0.05)$.
In the PMD group, the immunohistochemical expression of $\mathrm{p} 53$ and $\mathrm{p} 16^{\mathrm{INK} 4 \mathrm{a}}$ was not correlated ( $p>0.05)$. This study group presented higher means of hTERT positive cells (85.5) compared to p53 $(35.6 ; \mathrm{p}<0.0001)$ and $\mathrm{p} 16^{\mathrm{INK4a}}$ positive cells $(5.5$; $\mathrm{p}<0.0001)$. The OSCC cases did not show correlation between the three antibodies $(p>0.05)$. However, this group presented a significant difference when the means of $\mathrm{p} 16^{\text {INK4a }}$ positive cells (18.8) were compared to p53 $(56.7 ; \mathrm{p}<0.001)$ and hTERT positive cells $(66.7 ; \mathrm{p}<0.0001)$. 

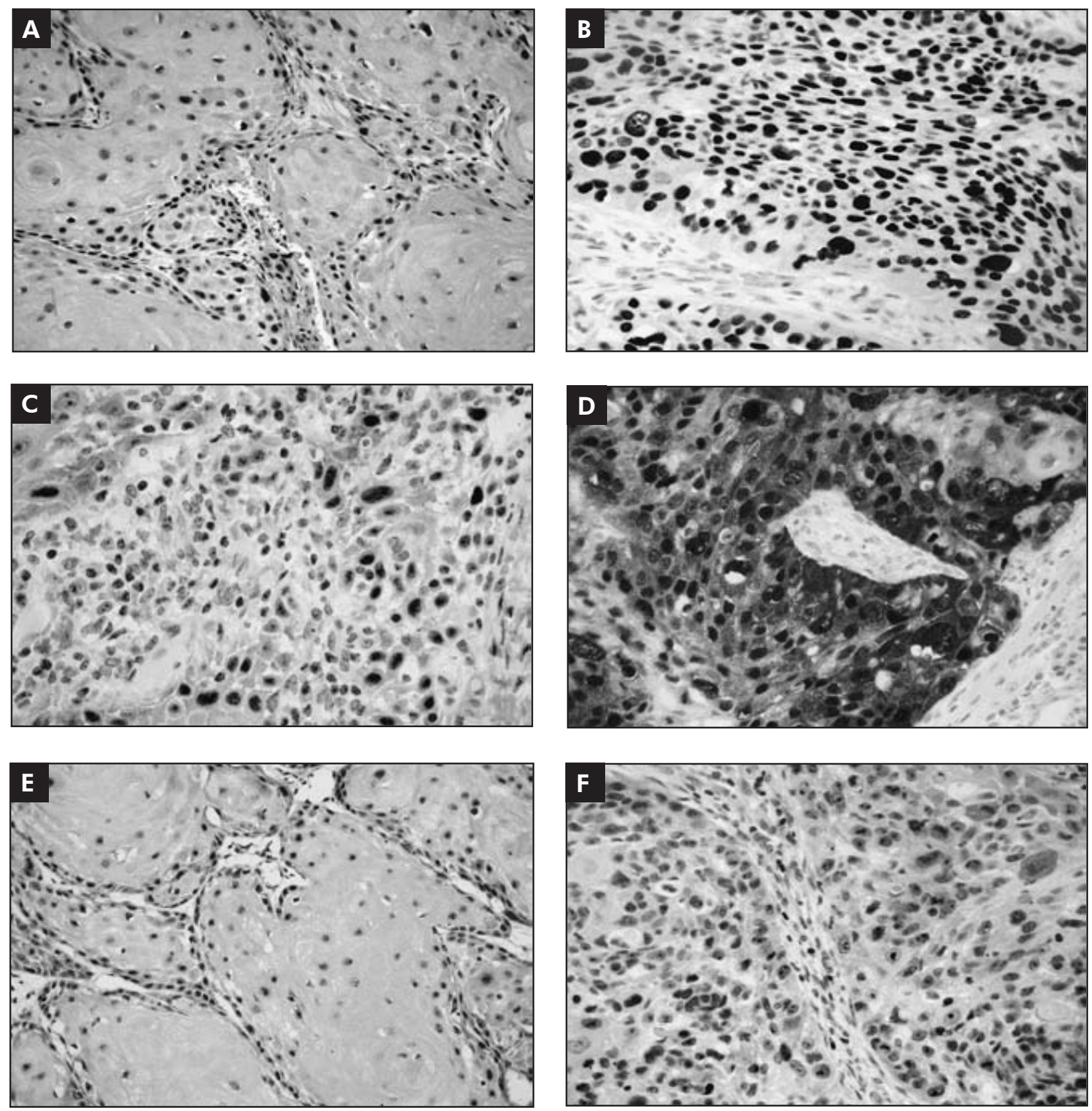

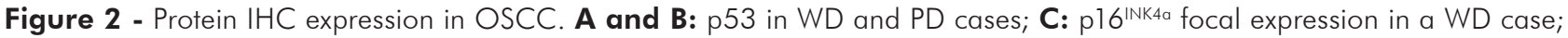
D: p16 $6^{\text {INK4a }}$ overexpression in a PD case; $\mathbf{E}$ and F: hTERT in WD and in PD cases. (SAB - original magnification 400x).

\section{Discussion}

Long-term retrospective reports have demonstrated that higher transformation rates to oral squamous cell carcinoma are not necessarily linked to severe grades of dysplasia. ${ }^{12,13}$ Also, reliable histological grading systems and prognostic markers are lacking for OSCC. ${ }^{14}$
In normal oral epithelium, p53 is restricted to the proliferative basal cell layer. ${ }^{3}$ Overexpression of inactivated or mutated forms of p53 in oral epithelial dysplasia has been associated with high risk for transformation to early stage OSCC. ${ }^{4}$ Cruz et al. showed that suprabasal p53 immunoexpression patterns are associated with high grades of dyspla- 
sia and correlate with progress to oral squamous cell carcinoma. ${ }^{3}$ According to the authors, expression pattern should be considered a predictive marker for malignant transformation, although malignant transformation also occurs in the absence of suprabasal p53 staining or dysplastic changes. ${ }^{3}$ In this study, p53 suprabasal expression was found in 2 cases of mild dysplasia and in all 5 severe dysplasia samples. No statistical significance was found among histological grades, possibly due to the small number of cases studied. However, suprabasal p53 immunoexpression may be a useful tool for malignant transformation risk assessment of potentially malignant disorders independent of dysplasia grade. Further studies with follow up are necessary to confirm this assumption.

p53 has been detected in a large percentage of OSCC cases by immunohistochemistry, reflecting the altered status of this protein..$^{15}$ More than $50 \%$ of our OSCC samples were p53 positive in accordance with the results described in the literature. Although we detected more cases of p53 positive WD-OSCC compared to PD-OSCC, this difference was not significant. Previous reports are inconclusive when relating p53 immunoexpression with the differentiation grade of OSCC..$^{5,15}$

Inactivation of the $\mathrm{p} 16^{\mathrm{INK} 4 \mathrm{a}}$ gene is frequently identified during early carcinogenesis. However, non-dysplastic mucosa and oral dysplastic lesions often lack positive $\mathrm{p} 16^{\mathrm{INK} 4 \mathrm{a}}$ immunohistochemical expression. ${ }^{16,17}$ Perhaps this lack of positive staining reflects that in non-dysplastic oral epithelium, normal $\mathrm{p} 16^{\mathrm{INK4a}}$ protein is below detection levels, whereas in epithelial dysplasia, the low expression is related to gene inactivation..$^{12}$ The significance of $\mathrm{p} 16^{\mathrm{INK} 4 a} \mathrm{im}$ munoexpression in OSCC is unknown but has been correlated with response to therapy, prognosis and tumor morphology. ${ }^{18}$ Among the studied OSCC, $18.8 \%$ were found positive for $\mathrm{p} 16^{\mathrm{INK} 4 \mathrm{a}}$. The $\mathrm{OEH}$ and PMD cases were positive in scattered groups of cells. These results suggest that $\mathrm{p} 16^{\mathrm{INK} 4 \mathrm{a}}$ is unrelated to the degree of dysplasia, although the small number of positive cases occurred in samples with mild and moderate dysplasia. These results may reflect either the frequent genetic inactivation of $\mathrm{p} 16^{\mathrm{INK} 4 \mathrm{a}}$ in early phases of carcinogenesis or the $\mathrm{p} 16^{\mathrm{INK} 4 \mathrm{a}} \mathrm{ex}$ - pression in slow cycling progenitor cells. ${ }^{19}$

Angiero et al. demonstrated an increase in p16 ${ }^{\mathrm{INK4a}}$ expression in higher grades of dysplasia and invasive OSCC. ${ }^{20}$ Likewise, Gologan et al. showed that $\mathrm{p} 16^{\mathrm{INK4a}}$ immunoexpression was able to highlight dysplastic areas in oral epithelium. ${ }^{16}$ However, Bradley et al. showed a significant trend toward absent expression of $\mathrm{p} 16^{\mathrm{INK} 4 \mathrm{a}}$ with increasing dysplasia severity. ${ }^{12}$ These different results are possibly due to the methodology or antibody used in the study. Other aspects that may influence immunohistochemical detection of $\mathrm{p} 16^{\mathrm{INK4a}}$ in OSCC are related to etiological factors. Different cancer-causing agents may lead to $\mathrm{p} 16^{\mathrm{INK4a}}$ gene inactivation as well as altered p53 and pRb tumor suppressive pathways. ${ }^{5,17}$ These changes may result in either loss or overexpression of $\mathrm{p} 16^{\mathrm{INK} 4 \mathrm{a}}$ in oral dysplasia and OSCC. HPV oncogenes are frequently found in oropharyngeal squamous cell carcinomas that display concomitant increased p16 ${ }^{\mathrm{INK} 4 \mathrm{a}}$ expression. ${ }^{17,21,22}$ According to Vidal and Gillison, patients with HPV-positive head and neck squamous cell carcinoma present better clinical outcomes compared to those with HPV-negative tumors. $^{22}$ Our study shows thirteen OSCC with p16 ${ }^{\mathrm{INK} 4 \mathrm{a}}$ expression, and viral participation cannot be discarded. Other relevant etiopathological agents that may influence $\mathrm{p} 16^{\mathrm{INK} 4 \mathrm{a}}$ expression are smoking and smoke-less tobacco use. ${ }^{21,23}$ The oral mucosa of smokers and lesions associated with smoke-less tobacco use express p $16^{\text {INK4a }}$ more frequently when compared to individuals that do not use tobacco. ${ }^{20,21}$

Telomerase activation is reported as a common event in oral carcinogenesis, and hTERT expression has been detected in epithelial cells of dysplastic oral mucosa. ${ }^{10}$ Low levels of hTERT mRNA have been reported in normal oral mucosa, with a gradual increase during malignant transformation. ${ }^{7}$ In the current investigation, all $\mathrm{OEH}$ and PMD cases were hTERT positive, and no correlation was found between hTERT and dysplasia grade. We suggest that the intense hTERT staining in the OEH and PMD groups may reflect a high proliferative cell capacity in oral lesions with epithelium presenting as hyperplasia and dysplasia. In normal oral epithelium, the hTERT expression is reported to be low when compared to hyperplastic or dysplastic oral epithelium. ${ }^{24}$ 
In oral carcinogenesis, telomerase expression may favor telomere stabilization and cell proliferation.

Telomerase activity is important in deregulated cell growth and escape from senescence, contributing to clonal expansion of dysplastic cells that harbor $\mathrm{p} 53$ and p16 $6^{\mathrm{INK} 4 \mathrm{a}}$ abnormalities. ${ }^{19,24}$ Chen et al. showed a correlation between cytoplasmic and nuclear hTERT expression in histologically different OSCC, suggesting that hTERT expression was a biomarker for this type of lesion. ${ }^{24}$ The authors reported that cytoplasmic hTERT was increased in dysplastic oral epithelium and OSCC compared to normal epithelium, whereas nuclear hTERT was decreased in OSCC. ${ }^{24}$ This work analyzed nuclear hTERT staining and found a higher hTERT expression in WD-OSCC compared to PD-OSCC. The mean number of hTERT positive cells in the WD group had a tendency to be higher than in the PD group. It is possible that in PD-OSCC, other mecha-

\section{References}

1. Barnes L, Eveson JW, Reichart P, Sidransky D. Editors. World Health Organization Classification of Tumours. Patholgy \& Genetics of Head and Neck Tumours. Lyon: IARC Press; $2005.430 \mathrm{p}$.

2. Mithani SK, Mydlarz WK, Grumbine FL, Smith IM, Califano JA. Molecular genetics of premalignant oral lesions. Oral Dis. 2007 Mar;13(2):126-33.

3. Cruz I, Napier SS, van der Waal I, Snijders PJ, Walboomers JM, Lamey PJ, et al. Suprabasal p53 immunoexpression is strongly associated with high grade dysplasia and risk for malignant transformation in potentially malignant oral lesions from Northern Ireland. J Clin Pathol. 2002 Feb;55(2):98-104.

4. Shah NG, Trivedi TI, Tankshali RA, Goswami JA, Shah JS, Jetly DH, et al. Molecular alterations in oral carcinogenesis: significant risk predictors in malignant transformation and tumor progression. Int J Biol Markers. 2007 AprJun;22(2):132-43.

5. de Oliveira LR, Ribeiro-Silva A, Zucoloto S. Prognostic impact of p53 and p63 immunoexpression in oral squamous cell carcinoma. J Oral Pathol Med. 2007 Apr;36(4):191-7.

6. Nakahara Y, Shintani S, Mihara M, Kiyota A, Ueyama Y, Matsumura T. Alterations of Rb, p16(INK4A) and cyclin D1 in the tumorigenesis of oral squamous cell carcinomas. Cancer Lett. 2000 Nov 10;160(1):3-8.

7. Freier K, Pungs S, Flechtenmacher C, Bosch FX, Lichter P, Joos $\mathrm{S}$, et al. Frequent high telomerase reverse transcriptase nisms are involved in maintaining telomere length such as alternative lengthening of telomeres. Future studies are needed to help clarify the contribution of telomere lengthening and telomere-associated proteins in oral carcinogenesis.

\section{Conclusion}

p53, p16 ${ }^{\mathrm{INK} 4 \mathrm{a}}$ and hTERT are not associated with the grade of dysplasia in PMD of the oral mucosa or with the differentiation degree of OSCC. However, suprabasal p53 immunoexpression was associated with severe grades of dysplasia. The results also show that $\mathrm{p} 16^{\mathrm{INK} 4 \mathrm{a}}$ may not be useful for distinguishing hyperplastic oral epithelium from dysplastic oral epithelium. The intense hTERT expression in OEH, PMD and OSCC suggests that telomerase activity is involved in the development of hyperplastic and dysplastic oral epithelium.

expression in primary oral squamous cell carcinoma. J Oral Pathol Med. 2007 May;36(5):267-72.

8. Gilley D, Tanaka H, Herbert BS. Telomere dysfunction in aging and cancer. Int J Biochem Cell Biol. 2005 May;37(5):100013.

9. Masutomi K, Hahn WC. Telomerase and tumorigenesis. Cancer Lett. 2003 May 15;194(2):163-72.

10. Luzar B, Poljak M, Marin IJ, Eberlinc A, Klopcic U, Gale N. Human telomerase catalytic subunit gene re-expression is an early event in oral carcinogenesis. Histopathology. 2004 Jul;45(1):13-9.

11. Warnakulasuriya S, Johnson NW, van der Waal I. Nomenclature and classification of potentially malignant disorders of the oral mucosa. J Oral Pathol Med. 2007 Nov;36(10):575-80.

12. Bradley KT, Budnick SD, Logani S. Immunohistochemical detection of p16INK4a in dysplastic lesions of the oral cavity. Mod Pathol. 2006 Oct;19(10):1310-6.

13. Arduino PG, Surace A, Carbone M, Elia A, Massolini G, Gandolfo S, et al. Outcome of oral dysplasia: a retrospective hospital-based study of 207 patients with a long follow-up. J Oral Pathol Med. 2009 Jul;38(6):540-4.

14. Brennan M, Migliorati CA, Lockhart PB, Wray D, Al-Hashimi I, Axell T, et al. Management of oral epithelial dysplasia: a review. Oral Surg Oral Med Oral Pathol Oral Radiol Endod. 2007 Mar;103 Suppl:S19.e1-12.

15. Gasco M, Crook T. The p53 network in head and neck cancer. Oral Oncol. 2003 Apr;39(3):222-31. 
16. Gologan O, Barnes EL, Hunt JL. Potential diagnostic use of p16INK4A, a new marker that correlates with dysplasia in oral squamoproliferative lesions. Am J Surg Pathol. 2005 Jun;29(6):792-6.

17. Karsai S, Abel U, Roesch-Ely M, Affolter A, Hofele C, Joos S, et al. Comparison of p16(INK4a) expression with p53 alterations in head and neck cancer by tissue microarray analysis. J Pathol. 2007 Feb;211(3):314-22.

18. Muirhead DM, Hoffman HT, Robinson RA. Correlation of clinicopathological features with immunohistochemical expression of cell cycle regulatory proteins p16 and retinoblastoma: distinct association with keratinisation and differentiation in oral cavity squamous cell carcinoma. J Clin Pathol. 2006 Jul;59(7):711-5.

19. Rheinwald JG, Hahn WC, Ramsey MR, Wu JY, Guo Z, Tsao H, et al. A two-stage, p16(INK4A)- and p53-dependent keratinocyte senescence mechanism that limits replicative potential independent of telomere status. Mol Cell Biol. 2002 Jul;22(14):5157-72.
20. Angiero F, Berenzi A, Benetti A, Rossi E, Del Sordo R, Sidoni $\mathrm{A}$, et al. Expression of p16, p53 and Ki-67 proteins in the progression of epithelial dysplasia of the oral cavity. Anticancer Res. 2008 Sep-Oct;28(5A):2535-9.

21. Greer Jr RO, Meyers A, Said SM, Shroyer KR. Is p16(INK4a) protein expression in oral ST lesions a reliable precancerous marker? Int J Oral Maxillofac Surg. 2008 Sep;37(9):840-6.

22. Vidal L, Gillison ML. Human papillomavirus in HNSCC: recognition of a distinct disease type. Hematol Oncol Clin North Am. 2008 Dec;22(6):1125-42, vii.

23. Tarakji B, Kujan O, Nassani MZ. An immunohistochemical study of the distribution of $\mathrm{p} 16$ protein in oral mucosa in smokers, non-smokers and in frictional keratosis. Med Oral Patol Oral Cir Bucal. 2010 Sep 1;15(5):e681-4.

24. Chen HH, Yu CH, Wang JT, Liu BY, Wang YP, Sun A, et al. Expression of human telomerase reverse transcriptase (hTERT) protein is significantly associated with the progression, recurrence and prognosis of oral squamous cell carcinoma in Taiwan. Oral Oncol. 2007 Feb;43(2):122-9. 